\title{
Long-term economic growth and investment: features of the relationship between the North and the Arctic of the Russian Federation
}

\author{
Alexander Kugaevsky*, and Anastasiia Dolgunova \\ M.K. Ammosov North-Eastern Federal University, 58 Belinsky Street, Yakutsk, 677891, Russia
}

\begin{abstract}
For the North and the Arctic constituent entities of the Russian Federation, the mechanism for the impact of investments on economic growth is quite specific due to special conditions of investment activities in the North. Investment processes in the northern territories are characterized by "extension" or increased duration of investment cycles, instability, but at the same time inertia. The results of the study reveal that "northerness", as well as the raw material orientation of the economy, make it difficult to determine the relationship between such indicators as "fixed investment" and "gross regional product", therefore, for these territories there is often no clear and statistically significant connection. The investment growth models in the strategic planning of the socio-economic development of these regions should be applied with due diligence and broad understanding of all the features and factors of economic growth in the North.
\end{abstract}

\section{Introduction}

Targeting the level and dynamics of investment is a trend of modern state economic policy in the Russian Federation: strategic planning documents consistently indicate the leading dynamics of fixed investments or a significant level of investment as the most important factor of the economic growth.

The Decree of the President of the Russian Federation of May 7, 2018 No. 204 "On National Goals and Strategic Objectives for the Development of the Russian Federation for the Period until 2024" [1] considers the entry of the Russian Federation into the five largest economies of the world, thus ensuring economic growth rates above the world levels, as one of the national development goals. According to the explanations of the Government of the Russian Federation, its achievement implies slightly higher economic growth rates (more than 3\%) [2]. The achievement of the desired growth rate is associated with the "investment growth model". This wording was given in 2018 by the Chairman of the Government of the Russian Federation D.A. Medvedev: "It is with the investment growth model that we associate plans to reach the desired growth rates. The share of investments in GDP is planned to increase from 21$22 \%$ to $25 \%$ in 2024 ". In the previous document, which determined the strategic goals and priorities of the socio-economic development of the Russian Federation (Decree of the President of Russia of May 7, 2012 No. 596 "On Long-term State Economic Policy" [3]), an increase in investment was established to at least $25 \%$ of gross domestic product by 2015 and to $27 \%$ by 2018 . According to Rosstat, the share of fixed investments in the country's GDP in 2015 was $20 \%$, in $2019-20.7 \%$ [4].

The relationship between the economic growth and investment dynamics is a fact that characterizes economic fluctuations, the existence of which is well known, but the correct application in practice is accompanied by certain difficulties.

The basic economic theory states that investment contributes to economic growth. The theory of modern economic growth considers investment in physical and human capital as correlates of economic growth. Empirical studies of economic growth and capital formation in the 1990s have largely led to the conclusion that investment has a significant impact on the economic growth. As an example, this was stated by the following authors: DeLong and Summers (1991, 1992) [5], Levin and Renelt (1992) [6]. Later, these studies have been criticized more than once, including by economist Robert Joseph Barro, as containing inflated estimates of this influence: the relationship between economic growth and investment may ultimately be characterized as direct but weak. The scientist's conclusions are based on a significant number of research works devoted to the determinants of the economic growth over the past thirty years (including the studies conducted in 1991, 1993, 1996, 1999, 2003, 2008 [7-12]). In his recent research Double Investment Account (2019) [13] Barro says that there is a double account of investment in the national income accounts.

The description of empirical studies of Russian authors suggests that at present the fixed investments 
are accepted as the most important factor in the economic growth of regional economies. At the same time, the specifics of working with this indicator are not always taken into account, for example, the need to consider its impact on economic growth with some lag, the bi-directional or inverse relationship between indicators is not supposed, the work mainly covers short time series.

\section{Methodology}

To study the regional features of the relationship between such indicators as "fixed investments" and "gross regional product", the series of dynamics were compiled according to official statistics published on the Rosstat website, in the context of all constituent entities of the Russian Federation from 2000 to 2017, i.e. for 18 years (the earlier period is not considered since mainly the economies of the regions and their investment activities were in a state of deep recession, and the financial and economic crisis in Russia in 1998 only aggravated this situation).

When phenomena are related not in the same period of time, but with some delay, it is necessary to measure the relationship of the factorial feature with the effective feature not by simultaneous levels, but by taking into account some lag. In the study, the lag is understood as the value that characterizes the time interval (number of years) of the relationship (joint variability) of "fixed investments" and "gross regional product", where the first is the cause, while the second is the consequence. The absolute values of these indicators are reduced to a single base year (2017). The lag value is determined by the correlation analysis. In
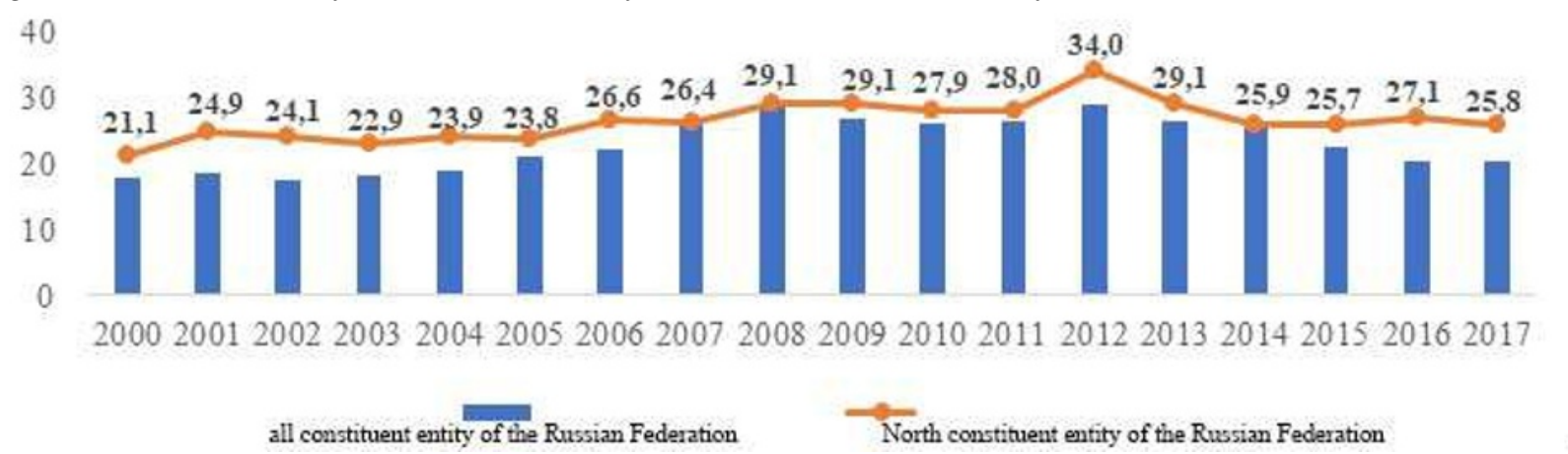

North constituent entity of the Russian Federation

Fig. 1. Median values of the share of investments in fixed assets in the gross regional product for the constituent

entities of the Russian Federation over 2000-2017

Then let us implement a retrospective analysis of the ratios between the values of the indicators "fixed view of the previously performed detrending, the correlation analysis was applied to deviations of individual levels from trends (the study assumes the hypothesis that the time series are stationary in relation to the trend).

Traditionally, the scientific research include the following constituent entities of the Russian Federation in the northern regions: Arkhangelsk, Murmansk, Sakhalin, Magadan regions, Nenets, Khanty-Mansi, Yamalo-Nenets, Chukotka Autonomous districts, Republic of Karelia, Komi, Sakha (Yakutia), Kamchatka Territory.

\section{Results and Discussion}

Investment projects are implemented in the regions. At the same time, the economy of each constituent entity of the Russian Federation always has objective development features, which imposes a certain imprint on the nature of the relationship between investment and growth of the regional economy. The economic dynamics of the constituent entity is also determined by other factors that, in terms of the effect size, may significantly exceed investments in fixed assets. Therefore, in order to effectively manage the region's economy, it is necessary to understand precisely the specifics of the relationship of indicators.

Projecting the national development goal to the regional level, i.e. to achieve an investment level of at least $25 \%$ of the gross regional product, it must be recognized that this sets the goal for half of the regions to do what they have only one step closer to (in the "best" years for the Russian economy) over the past more than 15 years. investments" and "gross regional product" in the regional context. 


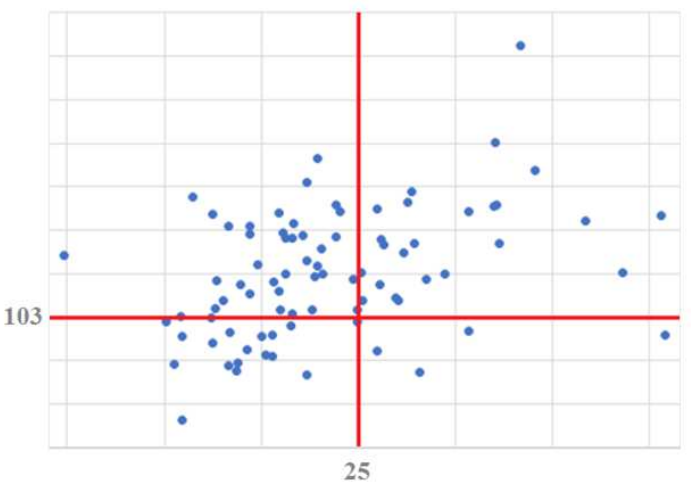

a

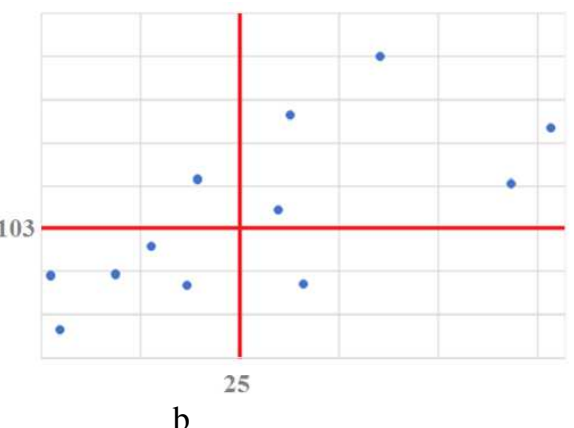

b

Fig. 2. Ratio of the average share of investments in fixed assets in the gross regional product (horizontal axis; $\%$ ) and the average growth of gross regional product (vertical axis; \%) in 2000-2017: a - for all constituent entities of the Russian Federation, $b$ - for northern constituent entities of the Russian Federation

The graphical analysis suggests that higher levels of investment usually correspond to higher economic growth. At the same time, more than $40 \%$ of constituent entities and with an investment level below $25 \%$ were able to ensure a $3 \%$ average annual growth of their economies. If we remove more successful years from the analysis, when the existing economic conditions could simultaneously predefine significant financial investments, i.e. high level of investment, and the growth of regional economies, then there is a change in the visualization of possible dependencies.

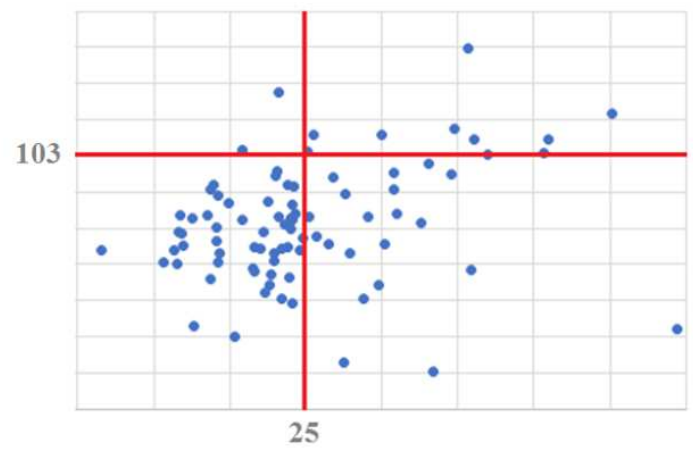

a

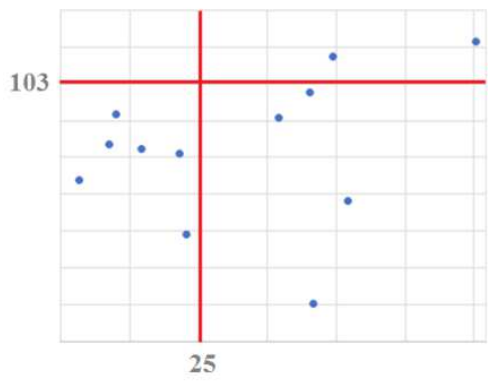

$\mathrm{b}$

Fig. 3. Ratio of the average share of investments in fixed capital in the gross regional product (horizontal axis) and the average growth of gross regional product (vertical axis) in 2013-2017: a - for all constituent entities of the Russian Federation, $b$ - for northern constituent entities of the Russian Federation

At this period, there are already much fewer regions that were able to achieve high growth rates of their economies at low level of investment. Most regions have an investment rate of less than $25 \%$ and an economic growth rate of less than $3 \%$. There are also significantly more regions with a high level of investment, but economic growth of less than $3 \%$ per year. For the northern regions, it may be stated even more unequivocally that the investment rate of $25 \%$ is not the key to high economic growth. Nevertheless, in the general conclusion that there may be a weak direct link between the studied indicators, for the northern regions it should be assumed that in order to achieve the accepted "high" economic growth, the level of investment should not just be "high", but "notably high".

Investments have a distinctive feature $-\mathrm{a}$ focus on future result from actions in the present and past, so it is quite natural to expect a temporary lag in the dynamics of the studied indicators. This process, as a rule, is extended over time: the period of design, project approval and decision making, the construction period or the purchase and installation of equipment, the period of reaching the design capacity and, finally, the first result of the economic (financial) return on investments.

The presence of a significant relationship of indicators, as well as the length of the lag, is determined in $82.9 \%$ of the regions of the Russian Federation ( 68 regions out of 82 analyzed). There is no lag, i.e. the relationship of indicators is manifested only "year-on-year", in 23 regions (28\%). The largest number of regions - 34 regions $(41.5 \%)$ - the relationship of indicators is significant over 2 years, namely, in the absence of a lag ("year-on-year") and with a lag of 1 year. A very small number of regions have a longer relationship: for 3 years -3 regions, 4 years -1 region. It is logical for the constituent entities of the northern macroregion to assume the predominance of prolonged investment cycles, however, according to the obtained results, it is impossible to unequivocally formulate this conclusion. 
The determination of group specifics for the Arctic zone of the Russian Federation was not carried out due to the impossibility of currently conducting a correct comparison of indicators for its territories [14]. At the same time, it is assumed that for the Arctic territories the northern specifics will be manifested to a much greater extent.

Table 1. Assessment of peculiarities of the relationship between "gross regional product" and "fixed investments" in time for the northern regions of the Russian Federation over 2000-2017.

\begin{tabular}{|c|c|c|}
\hline $\begin{array}{l}\mathrm{n} / \\
\mathrm{n}\end{array}$ & $\begin{array}{l}\text { Constituent } \\
\text { entity of the } \\
\text { Russian } \\
\text { Federation }\end{array}$ & $\begin{array}{l}\text { Time lag in the } \\
\text { relationship }\end{array}$ \\
\hline 1 & $\begin{array}{l}\text { Republic of } \\
\text { Karelia }\end{array}$ & $\begin{array}{l}\text { No time lag in the } \\
\text { relationship of the studied } \\
\text { indicators }(0 \mathrm{lag})\end{array}$ \\
\hline 2 & Komi Republic & $\begin{array}{l}\text { No time lag in the } \\
\text { relationship of the studied } \\
\text { indicators }(0 \mathrm{lag})\end{array}$ \\
\hline 3 & $\begin{array}{l}\text { Nenets } \\
\text { Autonomous } \\
\text { District }\end{array}$ & $\begin{array}{l}\text { Specifics in the relationship } \\
\text { in time (from } 1 \text { to } 2 \text { ) }\end{array}$ \\
\hline & $\begin{array}{l}\text { Arkhangelsk } \\
\text { Region (without }\end{array}$ & \\
\hline 4 & $\begin{array}{l}\text { Nenets } \\
\text { Autonomous } \\
\text { District) }\end{array}$ & Short lag (from 0 to 1 ) \\
\hline 5 & $\begin{array}{l}\text { Murmansk } \\
\text { Region }\end{array}$ & $\begin{array}{l}\text { No statistically significant } \\
\text { relationship }\end{array}$ \\
\hline 6 & $\begin{array}{l}\text { Khanty-Mansi } \\
\text { Autonomous } \\
\text { District-Ugra }\end{array}$ & $\begin{array}{l}\text { No statistically significant } \\
\text { relationship }\end{array}$ \\
\hline 7 & $\begin{array}{l}\text { Yamal-Nenets } \\
\text { Autonomous } \\
\text { District }\end{array}$ & $\begin{array}{l}\text { No statistically significant } \\
\text { relationship }\end{array}$ \\
\hline 8 & $\begin{array}{l}\text { Republic of } \\
\text { Sakha (Yakutia) }\end{array}$ & $\begin{array}{l}\text { No statistically significant } \\
\text { relationship } \quad \text { (zero-lag } \\
\text { correlation coefficient value } \\
0.395 \text { ) }\end{array}$ \\
\hline 9 & $\begin{array}{l}\text { Kamchatka } \\
\text { Territory }\end{array}$ & $\begin{array}{l}\text { No statistically significant } \\
\text { relationship }\end{array}$ \\
\hline 10 & Magadan Region & $\begin{array}{l}\text { Specifics in the relationship } \\
\text { in time (2-years lag) }\end{array}$ \\
\hline 11 & Sakhalin Region & $\begin{array}{l}\text { No statistically significant } \\
\text { relationship }\end{array}$ \\
\hline 12 & $\begin{array}{l}\text { Chukotka } \\
\text { Autonomous } \\
\text { District }\end{array}$ & $\begin{array}{l}\text { Specifics in the relationship } \\
\text { in time }\end{array}$ \\
\hline
\end{tabular}

In most cases, there is no statistically significant correlation of indicators for the northern regions with a resource-based economy. Besides, occasionally there are certain features in the relationship over time (Magadan Region, Chukotka Autonomous District). In the vast majority of the northern regions of the NorthWestern Federal District it is possible to find a statistically significant relationship between the indicators "fixed investments" and "gross regional product", and in some of them (Nenets Autonomous District and Arkhangelsk Region (without the Nenets Autonomous District)) there is some time lag in this relationship.
The absence of a statistically significant clear relationship between "fixed investments" and "gross regional product" for the northern regions with a resource-based economy may be explained by significant features of investment activities in the North, as well as the distinctive features of investment processes formed from them, including their influence on the duration of investment cycles and the stability of investment trends over time.

Special conditions for investment activities in the North may be formulated as follows:

- careful and long-term planning of all operations;

- limited transport accessibility;

- predominantly raw material focus;

- predominance of the corporate sector;

- special role of the state;

- complexity and specificity of construction in the North;

- special requirements for material and technical resources and technologies;

- shortage and high cost of manpower;

- low sustainability of environmental systems and, accordingly, special requirements for environmental protection [15].

These features predispose to the following characteristics in the dynamics of investment processes in the northern territories: "extension" or increased duration of investment cycles, instability (significant investment decline after the completion or sudden shutdown of the project), but at the same time inertia (investments may be continued contrary to crisis phenomena, for example, in case of accumulated safety margin, due to the scale of projects). As a result, these conditions significantly hamper economic and statistical modeling of these regions, which may be more effective if the time period of the study is increased (as confirmed for the Republic of Sakha (Yakutia) [16]) before the analysis according to the type of economic activity.

\section{Conclusion}

Despite the fact that macroeconomic dynamics is not indifferent to the ongoing investment processes, the quantitative increase in investment is not the main factor of the economic growth. The mechanism for the impact of investment on the economic growth has significant features for the northern regions of the Russian Federation due to special conditions for investment activities in the North. In the general conclusion that there may be a weak direct link between the studied indicators, for the northern regions it should be assumed that in order to achieve the accepted "high" economic growth, the level of investment should not just be "high" (25\%), but "notably high" (more than 35\%). Nevertheless, this factor of the "northern rise in price" as a feature of investment activities in the North is far from sufficient to assess the impact and success of investments, and the question of the quality of investments is still open. 


\section{References}

1. Decree of the President of the Russian Federation No. 204 "On national goals and strategic objectives for the development of the Russian Federation for the period up to 2024" (with amendments and additions) Retrieved from:

http://base.garant.ru/71937200/\#ixzz5WkF4I

$$
\text { Wis. }
$$

2. Main directions of activity of the Government of the Russian Federation for the period up to 2024 Retrieved from: http://www.consultant.ru/document/cons_doc LAW 307872/.

3. Decree of the President of the Russian Federation of No. 596 "On Long-Term State Economic Policy" etrieved from: http://base.garant.ru/70170954/\#ixzz5WkDBY $\underline{\mathrm{mFo}}$.

4. Official website of the Federal State Statistics Service (Rosstat) Retrieved from: http://www.gks.ru.

5. J. B.De Long, L. H. Summers, QuarterlyJournal of Economics 106 445-502 (1991)

6. R. Levine, D. Renelt, American Economic Review 82 942-63 (1992)

7. R. J. Barro, L. Jong-Wha, NBER Working Papers 4341, (1993)

8. R. J. Barro, The Quarterly Journal of Economics, 106(2), 407-443 (1991).

9. R. J. Barro, NBER Working Papers 5698, (1996)

10. R. J. Barro, NBER Working Papers 7038 (1999)

11. R. J. Barro, Annals of Economics and Finance, Society for AEF, 4(2), 231-274, (2003)

12. R. J. Barro, Asian Development Bank. 11, (2008)

13. R. J. Barro, NBER Working Papers 25826, (2019).

14. R. R. Nogovitsyin, V. A. Grigoryev, A. S. Lukovtseva, V. N. Markova, N. V. Prokhorova, J. A. Filippova, International Journal of Supply Chain Management, 8(5), October 2019, (2019).

15. A.T. Dolgunova, Regional economy: theory and practice, 17(12), (2019).

16. A.A. Kugaevsky, A.T. Dolgunova Bulletin of M.K. Ammosov Northeast Federal University. Series: Economics. Sociology. Cultural studies, 1 (17), (2020). 